\title{
THE BUSINESS OF STAYING DRY: DESIGNING WATERPROOF TEXTILES AND GARMENTS IN NINETEENTH-CENTURY NEW ZEALAND
}

Jane Malthus and Moira White

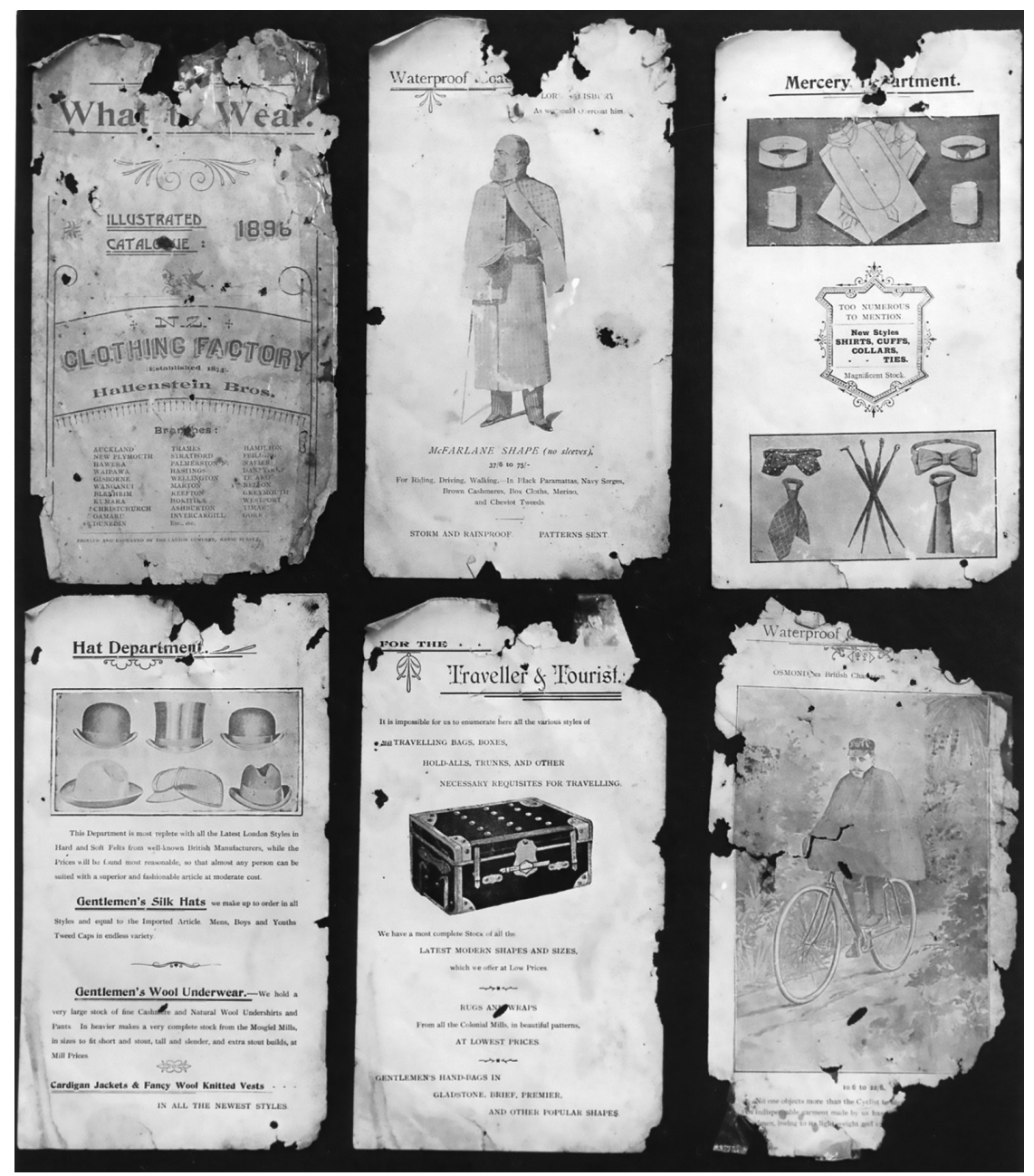

Figure I: Hallenstein Bros., image of 1896 Waterproof garments catalogue pages. Collection of Toitū Otago Settlers Museum, I 989 28.5- I. 
In New Zealand, waterproof and weatherproof clothing is often designed and marketed by romanticising rural activities, out-of-town travel and sporting pursuits in picturesque but rugged landscapes. Farmers mustering sheep or herding cattle, people getting out into the hills, or skiers and snowboarders posing in the mountains are familiar tropes in the advertising of such clothing. New Zealand's position as a group of islands in the southern hemisphere, exposed to weather coming from all directions, has meant that its human settlers needed garments for protection from rain, snow and wind. Maori used harakeke (Phormium tenax) and other plant materials such as kiekie for raincapes for centuries before Europeans arrived.' Unsurprisingly perhaps, British settlers, in conjunction with manufacturers in England, briefly investigated using the plentiful local flax plant to create covers and bags that would keep out the rain. Experiments with creating waterproof cloths from Phormium tenax, carried out in England it seems, were reported in the New Zealand Gazette and Wellington Spectator as early as August I843: "Mr. Donlan, the patentee of the waterproof cloth, delivered to Mr. Ball in 1837 a sufficient quantity of the waterproof fabric for a waggon [sic] cover; this cloth was put into use, and every stratagem was used to test its strength, soundness and durability, for a period of five years ..."'

It is not known if the waterproofing of the New Zealand flax cloth relied on properties of the fibres and weave or on some chemical additive, and while colonial experiments with making use of Phormium tenax continued throughout the nineteenth century, keeping people dry with waterproofed textiles followed a different path.

Chemical additives were first patented by Charles Macintosh in the United Kingdom in 1823. He developed a method of sandwiching rubber, softened by naphtha, between layers of cloth. By 1824 this cotton and rubber material began to be manufactured in Manchester. ${ }^{3}$ Naphtha is a flammable oil obtained by dry distillation of coal tar, shale or petroleum. Macintosh dissolved rubber in naphtha to produce a liquid, which was then brushed onto fabric, wool cloths initially.To make it really waterproof, he created a sandwich of two layers of this naphtha-treated fabric with moulded rubber between them. There were problems, however. Seaming the cloth caused holes where rain could penetrate; the natural oils in woollen cloth caused the rubber to deteriorate, and the fabric became stiff in cold and sticky in hot weather. ${ }^{4}$ According to the 1829 Gentleman's Magazine of Fashion, two further problems were the unpleasant smell and the shrinkage caused when one stood close to a fire. ${ }^{5}$

Multiple attempts to improve waterproof fabrics were made over the nineteenth century. After the textile-finishing calender process was developed in 1849 using heated rollers to create a smoother, shiny-surfaced fabric, American textile manufacturers experimented with calendering Macintosh's fabric, finding that it improved pliability and waterproofness. Thomas Hancock patented the vulcanisation or hardening process in 1843, which made rubber less sensitive to changes in temperature, so it was possible to then use a single coated fabric for waterproofed garments. ${ }^{6}$ Charles Goodyear refined that process, patenting his version in 1884. By late 1877 a Cravenette waterproofing process that could be applied to any textile without apparently changing its texture or weight was patented in Bradford, England," and "the new Cravenette waterproofs" arrived at Ballantyne and Co. in Christchurch, New Zealand, the same year. ${ }^{8}$ Experiments were made with substances other than rubber, too. Gutta percha (another latex), oils, fats, varnishes, waxes, acids and oxides were all used to waterproof fabrics. ${ }^{9}$ Oilskin, for instance, was a fabric such as cotton canvas with a skin of oil applied as waterproofing, used especially by sailors and miners, ${ }^{10}$ but it had the disadvantage of being very flammable.

Even with all these improvements and refinements waterproof fabrics were very heavy and hot and smelt bad, so garment designs had slits and vents to allow for air circulation." Pretty and fashionable they were not. In his A History of Men's Fashion, Farid Chenoune commented: "As to rubber raincoats, such as the Macintosh that appeared around 1840, they were hardly deemed stylish. Abel Léger nevertheless pointed out in his 1912 L'Elegance Masculine that "it is so practical that it can be excused for being ugly, for generally being smelly and for having all the unhealthy drawbacks of rubber which prevents evaporation of perspiration."'।2 
Ladies' waterproofs were just as bad: the only choice for many years, according to the Ladies' page of the Otago Witness in 1884, was "the sack-like waterproof cloth coat with sleeves fastening round the wrist with elastic" or "the hideous sticking plaster-like black mackintosh ... . It is only quite lately that the manufacturers of India-rubber waterproof clothing have seemed to think it desirable to rescue the fair sex from assuming the outward and visible guise of a refined kind of cabman or messenger."13

Macintoshes, rainproof and waterproof coats and mantles were being mentioned and advertised for sale in New Zealand to town and country dwellers from the very early days of print media: two Auckland suppliers advertised such stock "at reduced prices" in $1843 . .^{14}$ So-called "oiled waterproof" coats, leggings, jackets, sou'westers and pilot coats were being imported and sold by $1852 .{ }^{15}$ Thomson, Strang and Co. of Dunedin offered ladies' rainproof Oxford and Cambridge mantles in 1874. That same year, men's and boys' clothing from the New Zealand Clothing Factory (established the year before by the Hallenstein family), including waterproof coats, was being supplied to I. Hallenstein and Company's Lawrence shop. ${ }^{16}$ E. C. Brown and Company's Fashion House in Christchurch supplied their "distant customers" in the countryside with goods on a parcel system, such as a mourning parcel for $€ 2$ IOs that included "2 yds 4-4 celebrated rainproof crape."'17

Other newspaper references to waterproofs include this item from 1868 in Napier:Thomas Hitchings had his new black waterproof Inverness Cape with a black velvet collar stolen from a cloak room at a dinner for the Governor, and had to advertise for its return..$^{18}$ In 1882 a waterproof coat worth 2 pounds was a prize for the best Clydesdale bred by the exhibitor at the Clutha Agricultural and Pastoral Society's annual show. The coat was donated by Brown, Ewing, and Co., Dunedin. ${ }^{19}$ They also gave a waterproof coat as first prize for a brood mare in foal or "with foal at foot" at the Waitahuna Farmer's Club show in $1888 .{ }^{20}$

From these and other references, it seems that the term 'waterproof' was used for oilskins, fabrics made using the Macintosh process, heavily fulled woollen fabric garments and rubberised cloth, and that such garments were in demand as useful, and even prized, possessions.

The claims of waterproofness that these advertisements made mostly went unchallenged in nineteenth-century New Zealand. There were no standards or consumer organisations to verify the truthfulness of manufacturers' or retailers' claims. It seems that waterproofs did not keep one completely dry. In October I 874 the Otago Daily Times reprinted an article from the Timaru Herald:

We seem to be getting in spring all the wet, violent, unpleasant, uncertain weather which should, if the usual climatic programme had been adhered to, have varied the monotonous sunshine of last winter. It is, however, a consolation to know that the rain, vexatious as it is to dwellers in towns, and travellers by land or sea, is doing no end of real good to everybody. As the lambing season is just commencing continued drought would now be fatal. ... When, therefore, the sodden citizen wearily pulls off his third pair of dirty boots, and hangs up his dripping, leaky, meretricious macintosh, before he changes his sopping clothes, let him lay the flattering unction to his soul, that meat will be "down" before long, though wool is "up"..."

Recipes for do-it-yourself waterproofing abounded in newspapers. Both the Bay of Plenty Times and the Taranaki Herald suggested that travellers should wear good Scottish tweed rather than waterproof cloth. The tweed coat could be made waterproof by soaking for 24 hours in a solution of "sugar of lead" (lead acetate) and alum in "soft water," then drip-drying it. "The rain does not penetrate the treated cloth."'22

An early-twentieth-century Cutter's Practical Guide gave its tailors a recipe for waterproofing that involved soaking and boiling woollen cloth first in a solution of water, soap and glue, then after it was almost dry, soaking it in a bath of water, alum and salt. This would, the authors said, make the cloth rainproof while still being supple and comfortable to wear, but they did caution that it would not "turn ordinary cloth into Macintosh material."23 


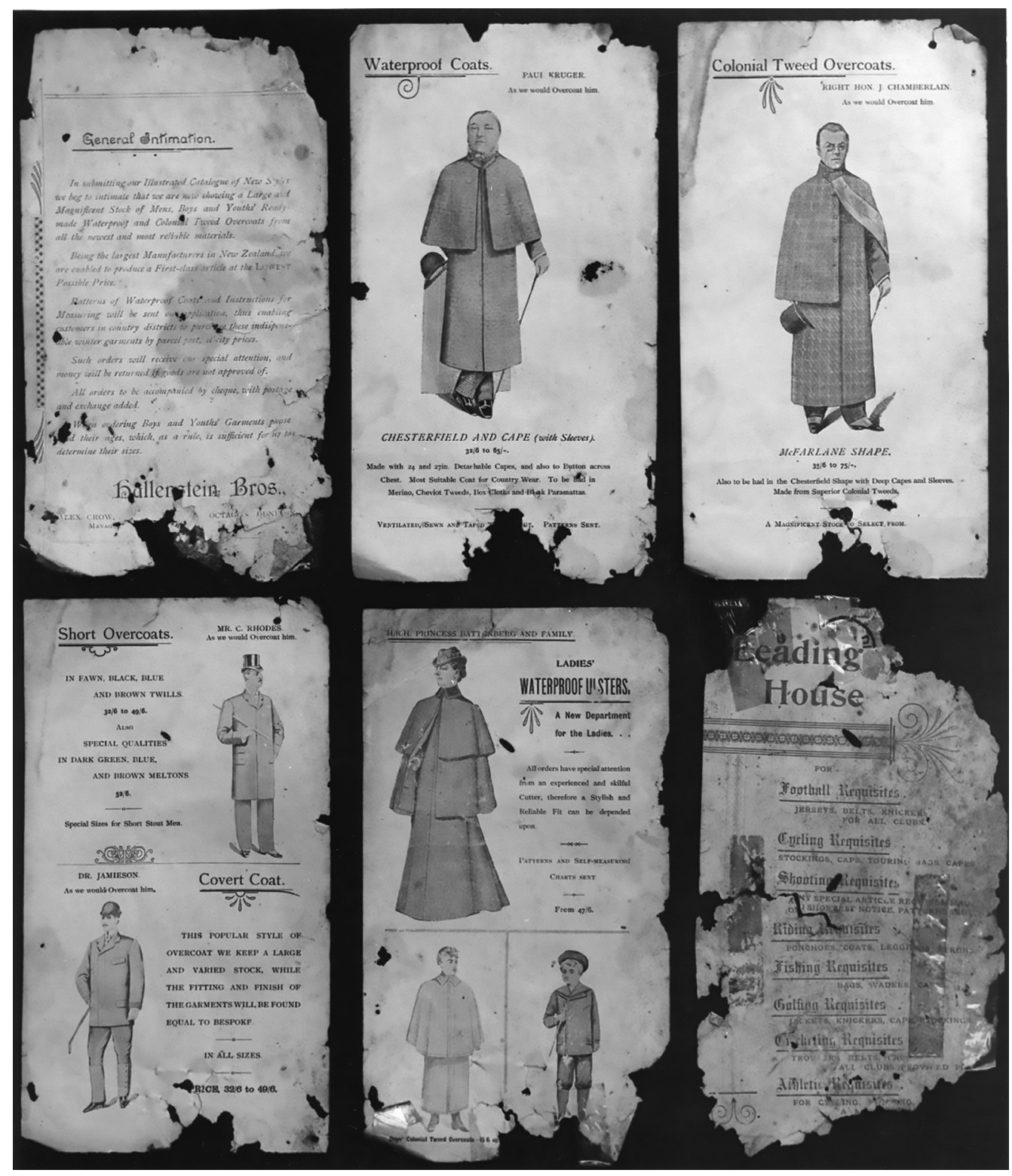

Figure 2. Image of Hallenstein Bros., I 896 waterproof garments catalogue pages. Collection of Toitū Otago Settlers Museum, 1989 28.5-2. 
With the New Zealand market for waterproofed clothing reportedly worth $£ 30,000$ per year, ${ }^{24}$ Hallenstein Brothers set up a separate waterproof factory in Dunedin in the late 1880s. This was announced in the Otago Daily Times of 22 October 1889 thus:

Some four months ago Messrs Hallenstein Bros, and Co. added the manufacture of ladies and gentlemen's waterproof clothing to their productions, and thus established an important industry. The manufacture is carried on in a building adjoining the New Zealand Clothing Factory. As the manufacture of waterproof clothing is a new one in New Zealand, the manager (Mr Allured) and an experienced staff had to be procured from the Home country. They have been busy since their arrival making up for the winter season a variety of goods, including men's Inverness capes, Chesterfields, ulsters, ladies' capes and cloaks, military regulation cloaks, waterproof buggy rugs, gaiters, leggings, cushions, sponge bags, \&c. The firm aim at manufacturing goods superior to those imported, and has procured several patent rights, including one for ventilation. The public will have an opportunity of inspecting these goods at the forthcoming exhibition, a bay having been procured in which to make an extensive show. ${ }^{25}$

Was this move taken because of increasing demand for such clothing on the part of rural and urban consumers, or were Hallensteins carried away with the possibilities offered by new technological processes, the challenges of meeting and exceeding the achievements of competitors, the opportunities for marketing, and the appeal of new products? Hallensteins were certainly aware of many British manufacturers or suppliers of waterproof clothing, listing some 37 different producers as potential suppliers in correspondence, but perhaps it was a combination of economics and experimentation that spurred them to try local production. ${ }^{26}$

New technological processes were certainly attempted. From Bendix Hallenstein's correspondence about supplies it is clear that the company was intending to produce a form of waterproofed cloth very similar to Charles Macintosh's. Hallenstein mentions the arrival of India rubber and naphtha (which continued to be mentioned in their annual accounts for some years), but also that a patent application had been unsuccessful, and that "Fairfax had copied the machinery and swindled us." There is mention, too, of an "explosion of the wonderful invention" - but it is unclear if that was just a colourful expression relating to the failure to get a patent, rather than an actual blow-up. ${ }^{27}$

While it is uncertain who is meant by the swindling claim, there had been an article in the Otago Daily Times, 20 days prior to the Hallensteins' announcement, that Messes Levy, Guthrie and Co. of Rattray Street were getting into the manufacture of waterproofs. ${ }^{28}$ Because piece goods could be imported duty-free - but coats and other waterproof ready-made garments attracted duty of 25 percent - it made commercial sense to import fabric (or buy it locally if one could) and make up ladies' and gents' waterproof coats, leggings, hats and stockings, combined boots and trousers for fishermen and boatmen, and possibly air and water beds. ${ }^{29}$

Other competitors in the waterproof garment business in the 1890s included more Dunedin firms: Lorie and Co., and the Zealandia Waterproofing Company. Zealandia, a company owned by the Taylor family, had brought a Mr Tennant out from Glasgow in 1889 to run their waterproof manufactory in High Street, Dunedin. They produced a very practical riding and driving coat, sleeveless, with a 24 -inch-deep cape, complete with "slings inside to act as rests for the arms when travelling" and tabs so that the cape could be formed into sleeves when driving a team of horses. Tabs also meant that the lower section of the coat could wrap around the legs when riding. This garment also came with a detachable hood. ${ }^{30}$

At the New Zealand and South Seas Exhibition of $1889-90$ in Dunedin, locally made and imported waterproof garments were displayed. Hallensteins won first prizes for "Ladies' colonial made waterproof mantles" and waterproof carriage rugs, air cushions and leggings. The Zealandia Waterproof Company won first prizes for their men's garments, with special mention made of the "Onslow" riding and driving coat, while Hallensteins came second in this category. English firms also took out prizes. Zealandia showed buggy rugs, waders and various styles of waterproof coats at the 189 | Otago Agricultural and Pastoral Society show, ${ }^{31}$ and that same year won the letter carriers' tender for supply of waterproof overcoats with capes at 39 s each. ${ }^{32}$ 
By 1900, Lorie's, who were near neighbours and staunch competitors of Hallenstein's NZ Clothing Factory "Lorie's stores lead for boys' and men's clothing," they claimed - had well-established men's and women's Macintosh departments, making their own designs from cloth imported "from the best Glasgow and Manchester makers." "With the exception of the very cheapest ones, every coat is double sewn and finished with glaze to prevent the water from soaking up the inside or sleeves" - and they offered their designs with or without sleeves. The cloths were wool as far as it is possible to tell. ${ }^{33}$

It seems that firms in competition with Hallensteins were importing their waterproofed cloth from companies such as David Moseley and Sons, of Manchester, ${ }^{34}$ and making it up into garments in New Zealand. Thomson and Beattie of Invercargill were open about their practice in 1892, stating that they held a large stock of waterproof materials in the piece, ready to make up into "Golden Wheel Waterproof garments" that were double-sewn throughout, but still cheaper than imported garments because the imported ones paid 25 percent duty. ${ }^{35}$

Country and small-town retailers also imported garments themselves. Draper E. Dimant of Lawrence predicted: "A rush will in all probability be made for the parcel of Ladies'Waterproof Cloaks just landed. These goods are ... stylish - Waterproof, neat, serviceable, and wonderfully cheap, even from IIs 6d each. Electric lining, freely selling and much to be desired." ${ }^{36}$ And Penrose's Drapery of Timaru stated: "Grumbling 'bout the weather is simply empty bosh; wiser far a hundredfold to don a Macintosh. We have 'em, prices 35s, 37s 6d, 45s, 55s for gents' macintoshes, ladies' macintoshes from 12s 6d to 60s." ${ }^{137}$

One advantage of New Zealand-made waterproof garments was that they were not perished by the voyage through the tropics. ${ }^{38}$ The Marlborough Express in 189 | claimed: "Not any fear of getting old stock, or a coat 'perished' by being imported, as they make up all their waterproofs and can safely recommend them. There is no danger of the garment coming to pieces as the coats are sewn throughout. Try the N.Z. Clothing Factory."39

Hallensteins advertised waterproof clothing made to order or off the rack at the DIC in Dunedin (their outlet for the upwardly mobile middle classes). ${ }^{40}$ In their illustrated catalogue of 1896, Hallensteins offered a range of new styles of ready-made men's, boys' and youths' waterproof and colonial tweed overcoats made "from all the newest and most reliable materials.' They also supplied patterns of waterproof coats and instructions for measuring to their country customers, so that they, too, could purchase "these indispensable winter garments by parcel post at city prices." ${ }^{\prime \prime}$ The catalogue showed the range as drawings on famous people of the day. A waterproof coat on Lord Salisbury, then British Prime Minister, was their McFarlane shape with a cape but no sleeves, suggested for riding, driving and walking, and available in a range of cloths and colours. Paul Kruger, State President of the South African republic, and the face of Boer resistance against the British during the Boer War of I899-1902, is shown wearing the Chesterfield and cape with sleeves, described as the most suitable coat for country wear. A new department offered waterproof ulsters to ladies, ${ }^{42}$ with patterns and self-measuring charts sent. Here the illustration featured $\mathrm{HRH}$ Princess Battenberg (Princess Beatrice, fifth daughter and youngest child of Queen Victoria) and two of her three sons (Alexander, Leopold and Maurice). ${ }^{43}$ Ulsters, with capes, had been available for women since the late 1870s. While the models had clear overseas pedigrees, the woollen and worsted fabrics were often from local mills such as Mosgiel, Kaiapoi and Roslyn.

New products, or at least new designs in existing materials, were developed, but it is hard to ascertain who thought of them first. Some coat designs were clearly so well known that the name alone told consumers what the garment looked like. Sargood Son and Ewen, established in Dunedin from 1869, ${ }^{44}$ offered their range of waterproof coats in 1898 in a charming catalogue.

The Paddock coat, a clever crossover of town and country, male and female, was a newish design in the late nineteenth century, although it is hard to determine where and when it was first created. It was a loose-fitting double-breasted coat with $2 \times 4$ buttons, flapped chest pocket on left front, flapped hip pockets, side back seams with pleats or vents. It had no side seams - just a vertical dart for shaping at each side, and no waist seam. Its sleeves were 

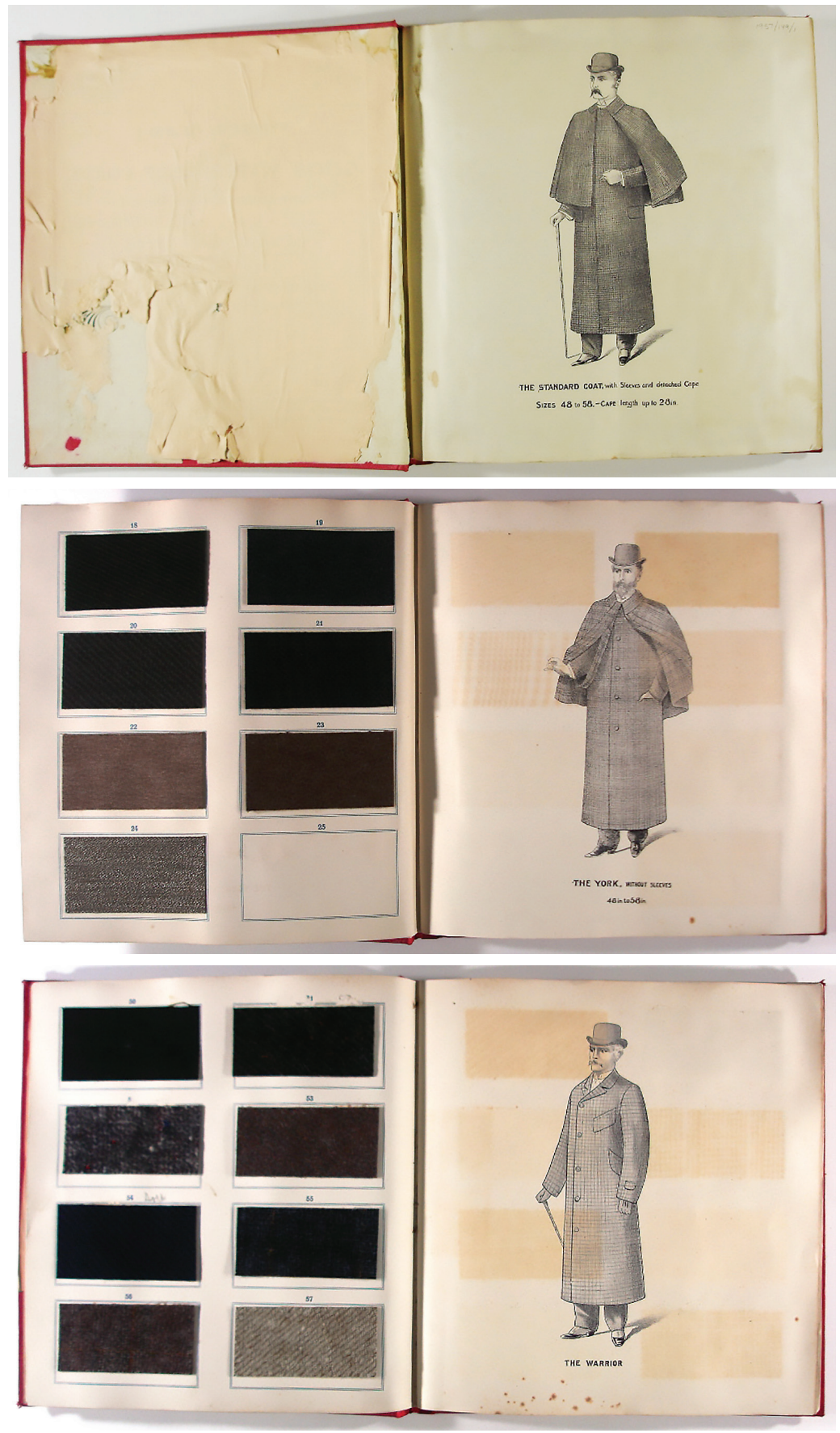

Figure 3a, 3b 3c. Selected pages from Samples of Waterproof Coats,

Sargood, Son and Ewen, Ltd, 1898.

Collection of Toitū Otago Settlers Museum, 1957//49/I. 
set in and loose fitting. ${ }^{45}$ Paddock coats were designed for sports and outdoor activities for both men and women, and usually advertised with macintoshes, oilskins and other "waterproof" items. The D.S.C. in Auckland had Paddock macintoshes, among other items, "selected by our London Buyer" " in 1898;46 George and Kersley of Wanganui had "Paddock Macintoshes" for sale in 1899;47 and James Smith, in Wellington, stated that they were in such demand that they had had been "compelled to supplement our first order."18

By the late nineteenth century, then, there was a flurry of activity surrounding waterproofing techniques, the supply of fabrics, the design of garments and the desire to protect customers from the elements. Despite early assessment and experimentation with plants endemic to New Zealand, European settler importers and manufacturers had supplied their fellow settlers from the northern hemisphere with less-than-stylish macintoshes, oiled waterproofs or thick heavy woollen overcoats. That these became prized garments was in part due to the variability of New Zealand's climate, as well as people's many outdoor activities. While some people did try home waterproofing, it seems, Hallenstein Brothers and others certainly attempted to develop techniques to waterproof quantities of fabric, and designed garments specifically for local conditions, albeit closely following European traditions. Competition among businesses drove improvements, fueled in part by the exhibitions that showcased business entrepreneurship. The most important thing was that increased availability of waterproof fabric, however and wherever it was made, meant that garment manufacturers could offer their town and country clients greater physical comfort and more protection in difficult environments. Perhaps they were also able to look more fashionable outdoors, either working or travelling. Entrepreneurship, business and marketing competition, technical and design innovation all combined to benefit both town and country consumers.

Jane Malthus is a dress historian and Honorary Curator for Dress at Otago Museum.

Moira White is Curator, Humanities at the Otago Museum, Dunedin. Her principal research areas involve the material culture collections of museums.

I Awhina Tamarapa, Whatu Kakahu/Maori Cloaks (Wellington:Te Papa Press, 20I I), 54, 55. "Flax - its Varieties," Daily Southern Cross, 16 June 1869, 5.

2 "New Zealand Flax," New Zealand Gazette and Wellington Spectator, 23 August I 843, 3.

3 Penelope Byrde, Nineteenth Century Fashion (London: BT Batsford, 1993), 135.

4 www.britannica.com/EBchecked/topic/354755/Charles-Macintosh.

5 Valerie Cumming, CW Cunnington and PE Cunnington, The Dictionary of Fashion History (Oxford: Berg, 20 I 0), 277.

6 Byrde, Nineteenth Century Fashion, 135.

7 Phyllis G Tortora and Robert S Merkel, Fairchild's Dictionary of Textiles, 7th ed. (New York: Fairchild Publications, 1996), 623. The description provided to the USPTO for "Cravenette" was "Chemical Compositions for Processing Fabrics and Garments Made of Wool, Cotton, and Synthetic Fibers and Blends Thereof to Make Them Water Repellent," www.trademarkia.com/ cravenette-71690067.html.

8 Star, 18 November 1887, 2.

9 Mary Brookes Picken, The Fashion Dictionary, rev. ed. (New York: Funk and Wagnalls, 1973), 407. Gutta percha is a latex substance obtained from trees grown mostly in the Malay Peninsula. 
I I "Raincoat," How Products are Made, Vol. 6, http://www.madehow.com/Volume-6/Raincoat.html\#b\#ixzz I ut I sjpOa.

12 Farid Chenoune, History of Men's Fashion (Paris: Flammarion, 1993), 124.

13 Otago Witness, 25 October 1884, 27.

14 Daily Southern Cross, 29 April I843, 2.

15 Thomas Weston and Co. advt. in New Zealander, 17 July 1852, I.

16 TuapekaTimes, 20 May 1874, I.

17 Akaroa Mail and Banks Peninsula Advertiser, I5 June 1883, 2. The parcel also included black cashmere, black alpaca, black hose, black gloves and $1 / 2$ dozen cambric handkerchiefs.

I8 Hawkes Bay Herald, 16 June 1868, 2.

19 Otago Daily Times, 29 November 1882, 3.

20 Otago Witness, 6 January $1888,16$.

21 Otago Daily Times, 19 October 1874, 2.

22 Bay of Plenty Times, 19 September 1894, 4; Taranaki Herald, 24 August 1870, 3.

23 The Cutter's Practical Guide: Ladies' Garments (London:The John Williamson Company Ltd., n.d. [prob. I906], 23.

24 Otago Daily Times, 2 October 1889,6.

25 Otago Daily Times, 22 October 1889, 2.

26 Hallenstein Records, Hocken Collection Archives ARC-004I, AG 295-039/025.

27 Bendix Hallenstein correspondence, 8, 9 August 1889. Hocken Collection Archives ARC-004I, AG296. No mention of the explosion seems to have been made in the local press.

28 Otago Witness, 3 I March 1898, 33, reported that Messrs Levy, Guthrie and Co. had begun to produce waterproof materials on 14 September 1889.

29 "A New Industry," Otago Daily Times, 2 October 1889, 6.

30 Otago Daily Times, 4 February I890, 3. (Both Taylor and Tennant had links with Sargood Son and Ewen, another firm prominent in nineteenth-century Dunedin.)

31 Otago Daily Times, 28 November I89I, Supplement, I.

32 Otago Daily Times, 18 August 189I, 4. By 1900 Zealandia may have changed or morphed into the British and Colonial Waterproof Company, which, under the management of Mr John Tennant, provided waterproof sheeting for Boer War contingents (Otago Daily Times, 23 February 1900, 5).

33 Otago Witness, 3 May 1900, 21 -2.

34 Otago Daily Times, 9 March 1889, 5.

35 Southland Times, 8 October 1892, 2. According to an advertisement in the Southland Times, I | August | 89|, 3, "Golden Wheel Clothing" was the new brand for garments made in Thomson and Beattie's workroom.

36 TuapekaTimes, 6 April 1892, 3.

37 Timaru Herald, 26 May 1898, 2.

38 Marlborough Express, 5 June 1895, I.

39 Marlborough Express, II May |891, 2.

40 Bruce Herald, 7 December 1894, 3.

41 Hallenstein Bros., 1896 catalogue.

42 For example, in the Marlborough Express, 17 March 1894, 2, Hallenstein Bros. and Co. included ladies' macintoshes in the eight different shapes it offered at its NZCF Blenheim branch.

43 http://en.wikipedia.org/wiki/Princess_Beatrice_of_the_United_Kingdom.

44 Otago Daily Times, 9 February 1869, I.

45 http://en.wikipedia.org/wiki/File:Paddockcoatd_jan 1904.jpg and Norah Waugh, The Cut of Men's Clothes (New York: Routledge, 1964), 148.

46 Auckland Star, 24 September 1898, 7.

47 Wanganui Chronicle, 4 April 1899, 2.

48 Manawatu Standard, 17 April 1899, 2. 